FEMSRE 00133

\title{
Hyperthermophilic microorganisms
}

\author{
K.O. Stetter, G. Fiala, G. Huber, R. Huber and A. Segerer \\ Lehrstuhl für Mikrobiologie, Universität Regensburg, Regensburg, F.R.G.
}

Key words: Hyperthermophiles; Taxonomy

\section{INTRODUCTION}

The most extremely thermophilic living beings known to date are bacteria growing at temperatures between 80 and $110^{\circ} \mathrm{C}[1-3]$. Some of them are so well adapted to the high temperatures that they do not even grow below $80^{\circ} \mathrm{C}$ [4]. As a rule, non of these hyperthermophilic bacteria are able to grow at $60^{\circ} \mathrm{C}$ or below. Hyperthermophiles are occurring mainly within the archaebacterial kingdom [5]; some of them are also present within the eubacteria [6,7]. Due to their existence within phylogenetically highly divergent groups, the lack of closely related mesophiles, and their biotopes existing already since the Archean age, hyperthermophiles may have adapted to the hot environment already billions of years ago.

\section{BIOTOPES}

The hyperthermophilic bacteria known at present have been isolated from submarine hydrothermal areas and from continental solfataras. The surface of the solfataras is usually rich. in sulfate and exhibits an acidic $\mathrm{pH}(0.5$ to $6 ;[1,2])$. In the depth, solfataras are less acidic or even neutral (pH 5 to 7 ; [8]). Sometimes, solfataric fields may also contain some weakly alkaline hot springs $(\mathrm{pH}$

Correspondence to: K.O. Stetter, Lehrstuhl für Mikrobiologie, Institute for Biochemistry, Genetics and Microbiology, University of Regensburg, Universitätsstr. 31, P.O. Box 397, D-8400 Regensburg, F.R.G.
7 to 9) rich in $\mathrm{NaCl}$. Also man-made hot environments such as the boiling outflows of geothermal power plants are suitable environments for hyperthermophiles [9]. Submarine hydrothermal systems are slightly acidic to alkaline ( $\mathrm{pH} 5$ to 8.5 ) and normally contain high amounts of $\mathrm{NaCl}$ and $\mathrm{SO}_{4}^{2-}$ due to the presence of sea water (Table 1). Due to the low solubility of oxygen at high temperatures and the presence of reducing gases, most biotopes of hyperthermophiles are anaerobic. Within continental solfataric fields, oxygen is only present within the upper acidic layer which appears ochre-coloured due to the existence of ferric iron [8].

Although not growing below $60^{\circ} \mathrm{C}$, hyperthermophiles are able to survive at low temperatures at least for years. Some of the anaerobic hyperthermophiles are able to tolerate oxygen much better at low (non-growth) temperatures than at high (growth) temperatures. This property max be essential for dispersal of these organisms through oxygen-rich low-temperature areas.

\section{TAXONOMY OF HYPERTHERMOPHILIC BACTERIA}

Up to now, about 35 different species of hyperthermophilic bacteria are known. They belong to different taxa within the eu- and archaebacteria (Table 2). Within the eubacteria, hyperthermophiles are within the Thermotogales order, which is the deepest phylogenetic branch-off based on 16S rRNA sequences within this kingdom [7]. The phylogenetic tree within the archaebacterial king- 
dom exhibits two main branches: the branch containing methanogens and halophiles and the branch of the sulfur metabolizing archaebacteria [7]. The latter consists almost exclusively of hyperthermophiles $[3,7]$ while there are only a few groups of hyperthermophiles within the other branch (Archaeoglobales, Thermococcales, Methanothermaceae, Mc. jannaschii). Within the sulfur metabolizers, acidophilic (e.g. Sulfolobus, Metallosphaera, Acidianus) and neutrophilic (e.g. Pyrodictium, Desulfurococcus, Staphylothermus, Thermococcus) genera were discovered during the last years. Therefore, the old designation "Thermoacidophiles" which was primarily used to characterize the genera Sulfolobus and Thermoplasma [1] is not suitable anymore for the designation of this branch.

\subsection{Extremely acidophilic hyperthermophiles}

Extremely acidophilic hyperthermophiles were found up to now exclusively within continental solfataric fields. The organisms are coccoid-shaped strict and facultative aerobes. They are extreme acidophiles due to their requirement of acidic $\mathrm{pH}$ (opt. approx. pH 3). Phylogenetically, they belong to the archaebacterial genera Sulfolobus, Metallosphaera, Acidianus, and Desulfurolobus. The less extremely thermophilic archaebacterium Thermoplasma is an extreme acidophile, too. It is a facultative anaerobe occurring both in smoldering coal refuse piles and continental solfataric fields $[1,10]$.

Members of the genus Sulfolobus are strict aerobes growing autotrophically by oxidation of -

Table 1

Biotopes of hyperthermophilic bacteria

\begin{tabular}{|c|c|c|}
\hline \multirow[t]{2}{*}{ Characteristics } & \multicolumn{2}{|l|}{ Type of thermal area } \\
\hline & Solfataric fields & Submarine hydrothermal systems \\
\hline Sites & $\begin{array}{l}\text { Steam-heated mud holes, } \\
\text { soils and surface waters; } \\
\text { deep hot springs; geo- } \\
\text { thermal power plants }\end{array}$ & Hot sediments and vents \\
\hline Temperatures & Up to $100^{\circ} \mathrm{C}$ & Up to about $374^{\circ} \mathrm{C}$ \\
\hline $\mathrm{pH}$ & 0.5 to 9 & 5 to 8.5 \\
\hline Presence of $\mathrm{O}_{2}$ & Surface oxic; depth anoxic & Anoxic \\
\hline $\begin{array}{l}\text { Major gases and } \\
\text { sulfur compounds }\end{array}$ & $\mathrm{CO}_{2}, \mathrm{CO}, \mathrm{CH}_{4}, \mathrm{SO}_{4}^{2-}, \mathrm{NH}_{4}^{+}$ & $\mathrm{H}_{2}, \mathrm{H}_{2} \mathrm{~S}, \mathrm{~S}^{0}, \mathrm{SO}_{3}^{2-}$ \\
\hline
\end{tabular}

$\mathrm{S}^{0}$ and $\mathrm{S}^{2-}$, forming sulfuric acid (Table 3, 4). Many Sulfolobus isolates are facultative heterotrophs and a few, still unnamed, are even strict heterotrophs (Stetter, unpublished). The type strain of Sulfolobus acidocaldarius (DSM 639) shows excellent growth on organic matter [11]. Autotrophically cultured on $\mathrm{S}^{2-}$ and $\mathrm{S}^{0}$, however, this strain shows only extremely weak growth and sulfuric acid formation [12-14]. Some members of the Sulfolobales like Metallosphaera sedula are able to oxidize sulfidic ores like pyrite, chalcopyrite and sphalerite, forming sulfuric acid and solubilizing the heavy metal ions (Table 3,$4 ;[15]$ ). Under microaerophilic conditions, Sulfolobus is able to reduce ferric iron and molybdate, which therefore act as electron acceptors under these conditions $[16,17]$. Members of the genus Sulfolobus grow only at very low ionic strength and were therefore not found within the marine environment ([11]; Segerer and Stetter, unpublished). Members of the genus Acidianus similar to Sulfolobus are able to grow by oxidation of $\mathrm{S}^{0}$, forming sulfuric acid $[18,19]$. Some strains grow also on sulfidic ores, but much less efficient than Metallosphaera (Table 4; [14]). In addition, members of Acidianus are able to grow by anaerobic oxidation of $\mathrm{H}_{2}$, using $\mathrm{S}^{0}$ as electron donor (Table 4; [18]). A thermoacidophilic isolate, which had been tentatively named "Sulfolobus ambivalens" [20] was later described as Desulfurolobus ambivalens, representing a new genus [21]. By DNA : DNA hybridization, however, Desulfurolobus ambivalens shows a close relationship to the 
- Table 2

Taxonomy of hyperthermophilic archaebacteria

\begin{tabular}{|c|c|c|}
\hline Order & Genus & Species \\
\hline \multicolumn{3}{|l|}{ I. Eubacterial kingdom } \\
\hline \multirow[t]{6}{*}{ Thermotogales } & Thermotoga & T. maritima \\
\hline & & T. neapolitana \\
\hline & & $T$. thermarum \\
\hline & Thermosipho & T. africanus \\
\hline & Fervidobacterium ${ }^{a}$ & $F$. nodosum \\
\hline & & F. islandicum \\
\hline \multicolumn{3}{|c|}{ II. Archaebacterial kingdom } \\
\hline \multirow[t]{6}{*}{ Sulfolobales } & Sulfolobus & S. acidocaldarius \\
\hline & & S. solfataricus \\
\hline & Metallosphaera & M. sedula \\
\hline & Acidianus & A. infernus \\
\hline & & A. brierleyi " \\
\hline & Desulfurolobus & D. ambivalens \\
\hline \multirow[t]{10}{*}{ Thermoproteales } & Thermoproteus & $T \cdot$ tenax \\
\hline & & T. neutrophilus \\
\hline & Pyrobaculum & $P$. islandicum \\
\hline & & P. organotrophum \\
\hline & Thermofilum & $T$. pendens \\
\hline & & T. librum \\
\hline & Desulfurococcus & D. mobilis \\
\hline & & D. mucosus \\
\hline & & D. saccharovorans \\
\hline & Staphylothermus. & $S$. marinus \\
\hline \multirow[t]{4}{*}{ Pyrodictiales } & Pyrodictium & P. occultum \\
\hline & & P. brockii \\
\hline & & P. abyssum \\
\hline & Thermodiscus & $T$. maritimus \\
\hline \multirow[t]{4}{*}{ Thermococcales } & Thermococcus & $T$. celer \\
\hline & & $T$. stetteri \\
\hline & Pyrococcus & P. furiosus \\
\hline & & P. woesii \\
\hline \multirow[t]{2}{*}{ Archaeoglobales } & Archaeoglobus & A. fulgidus \\
\hline & & A. profundus \\
\hline \multirow[t]{2}{*}{ Thermoplasmales " } & Thermoplasma & T. acidophilum \\
\hline & & $T$. volcanium \\
\hline \multirow[t]{2}{*}{ Methanobacteriales ${ }^{b}$} & Methanothermus & M. fervidus \\
\hline & & M. sociabilis \\
\hline \multirow[t]{2}{*}{ Methanococcales } & Methanococcus ${ }^{b}$ & $\begin{array}{l}\text { M. thermolitho- } \\
\text { trophicus }\end{array}$ \\
\hline & & M. jannaschii \\
\hline
\end{tabular}

Growth only up to about $70^{\circ} \mathrm{C}$, mentioned due to their close relationship to hyperthermophiles

b Contain also mesophilic species.

type species of Acidianus, Acidianus infernus [22]. Members of the genus Acidianus are able to grow in the presence of up to $4 \%$ salt. In agreement with this result, they also have been isolated (rarely) from a marine hydrothermal system [19].
3.2. Slightly acidophilic and neutrophilic hyperthermophiles

Slightly acidophilic and neutrophilic hyperthermophiles were found both in continental solfataric fields and in submarine hydrothermal systems and they show specific adaptations to their environments. All of them are strict anaerobes. Solfataric fields contain members of the genera Thermoproteus, Pyrobaculum, Thermofilum, Desulfurococcus, and Methanothermus (Table 3; [9,23-26]). Cells of members of the genera Thermoproteus, Pyrobaculum, and Thermofilum are characteristically stiff rods with protruding spheres ("golf clubs") mainly at their ends, possibly due to a mode of budding. Cells of Thermofilum are only about 0.17 to 0.35 $\mu \mathrm{m}$ in width and are therefore different from Thermoproteus and Pyrobaculum. Thermoproteus tenax, Thermoproteus neutrophilus and Pyrobaculum islandicum are able to grow autotrophically by anaerobic reduction of $\mathrm{S}^{0}$ with $\mathrm{H}_{2}$ as electron donor $[9,27]$. Strains of Thermofilum and Pyrobaculum organotrophum are obligate heterotrophs. They are growing by sulfur respiration, using different organic substrates (Table 4). Thermofilum pendens shows an obligate requirement for a lipid fraction of Thermoproteus tenax. Thermoproteus tenax and Pyrobaculum islandicum are also able to grow heterotrophically by sulfur respiration (Table 4). Also in solfataric fields coccoid heterotrophic organisms occur which gain energy by respiring organic material using sulfur as electron acceptor. They belong to the genus Desulfurococcus [25]. From solfataras in the southwest of Iceland, rod-shaped methanogens growing at temperatures up to $97^{\circ} \mathrm{C}$ (Table 3) were isolated $[26,28]$. Two species are known: Methanothermus fervidus and Methanothermus sociabilis, cells of the latter growing in clusters up to $3 \mathrm{~mm}$. Both species are strict autotrophs, gaining energy by reduction of $\mathrm{CO}_{2}$ by $\mathrm{H}_{2}$ (Table 4). Within neutral continental hot springs in Djibouti, Africa, the extremely thermophilic eubacterial species Thermotoga thermarum was found, which grows only at low ionic strength (Table 3,4; [29]). Members of this group are strictly anaerobic heterotrophs, growing by fermentation of carbohydrates. Most of them are found within the marine biotopes, however.

Many hyperthermophiles are adapted to the 
Table 3

Growth conditions and morphological and biochemical features of hyperthermophiles

\begin{tabular}{|c|c|c|c|c|c|c|c|c|}
\hline \multirow[t]{3}{*}{ Species } & \multicolumn{6}{|c|}{ Growth conditions } & \multirow{3}{*}{$\begin{array}{l}\text { DNA } \\
(\mathrm{mol} \% \\
G+\mathrm{C})\end{array}$} & \multirow[t]{3}{*}{ Morphology } \\
\hline & \multicolumn{3}{|c|}{ Temperature $\left({ }^{\circ} \mathrm{C}\right)$} & \multirow[t]{2}{*}{$\mathrm{pH}$} & \multirow{2}{*}{$\begin{array}{l}\text { Aerobic (ae) } \\
\text { anaerobic (an) }\end{array}$} & \multirow{2}{*}{$\begin{array}{l}\text { Habitat } \\
(\text { marine }(m) / \\
\text { solfataric }(s))\end{array}$} & & \\
\hline & Minimum & Optimum & Maximum & & & & & \\
\hline Sulfolobus acidocaldarius & 60 & 80 & 85 & $1-5$ & ae & $\mathbf{s}$ & 37 & Lobed cocci \\
\hline Metallosphaera sedula & 50 & 75 & 80 & $1-4.5$ & ae & s & 45 & Cocci \\
\hline Acidianus infernus & 60 & 88 & 95 & $1.5-5$ & ae/an & $\mathbf{s}$ & 31 & Lobed cocci \\
\hline Thermoplasma volcanium & 33 & 60 & 67 & $1-4$ & ae/an & $\mathbf{s}$ & 38 & Irregular cocci \\
\hline Thermoproteus tenax & 70 & 88 & 97 & $2.5-6$ & an & $\mathbf{s}$ & 56 & $\begin{array}{l}\text { Rods with terminally } \\
\text { protruding spheres }\end{array}$ \\
\hline Pyrobaculum islandicum & 74 & 100 & 103 & $5-7$ & an & $\mathbf{s}$ & 46 & $\begin{array}{l}\text { Rods with terminally } \\
\text { protruding spheres } \\
\text { Rods with terminally }\end{array}$ \\
\hline Pyrobaculum organotrophum & 78 & 100 & 102 & $5-7$ & an & $\mathbf{s}$ & 46 & protruding spheres \\
\hline Thermofilum pendens & 70 & 88 & 95 & $4-6.5$ & an & $\mathbf{s}$ & 57 & $\begin{array}{l}\text { Slender rods with } \\
\text { terminal spheres }\end{array}$ \\
\hline Desulfurococcus mobilis & 70 & 85 & 95 & $4.5-7$ & an & $\mathbf{s}$ & 51 & Cocci \\
\hline Staphylothermus marinus & 65 & 92 & 98 & $4.5-8.5$ & an & $\mathbf{m}$ & 35 & Cocci in aggregates \\
\hline Pyrodictium occultum & 82 & 105 & 110 & $5-7$ & an & $\mathrm{m}$ & 62 & Discs with fibres \\
\hline Pyrodictium abyssum & 80 & 100 & 110 & $4.7-7.5$ & an & $\mathrm{m}$ & 60 & Discs with fibres \\
\hline Thermodiscus maritimus & 75 & 88 & 98 & $5-7$ & an & m & 49 & Discs \\
\hline Thermococcus celer & 75 & 87 & 97 & $4-7$ & an & m & 57 & Cocci \\
\hline Pyrococcus furiosus & 70 & 100 & 103 & $5-9$ & an & m & 38 & Cocci \\
\hline Archaeoglobus fulgidus & 60 & 83 & 95 & $5.5-7.5$ & an & m & 46 & Irregular cocci \\
\hline Methanothermus sociabilis & 65 & 88 & 97 & $5.5-7.5$ & an & s & 33 & Rods in clusters \\
\hline Methanococcus jannaschii & 50 & 85 & 86 & $5.5-6.5$ & an & $\mathbf{m}$ & 31 & Irregular cocci \\
\hline Thermotoga maritima & 55 & 80 & 90 & $5.5-9$ & an & m & 46 & Rods with sheath \\
\hline Thermotoga thermarum & 55 & 70 & 84 & $6-9$ & an & s & 40 & Rods with sheath \\
\hline
\end{tabular}

marine thermal environments (Table 3). They are represented by the genera Staphylothermus, Pyrodictium, Thermodiscus, Thermococcus, Pyrococcus, Archaeoglobus, and by members of the genera Methanococcus and Thermotoga (Table 3; $[3,4,6,30-34])$. The organisms with the highest growth temperatures known are members of the genus Pyrodictium, growing up to $110^{\circ} \mathrm{C}[4,35]$. Cells of Pyrodictium are so well-adapted to high temperatures that they do not even grow below $80^{\circ} \mathrm{C}$ (Table 3). Cultures of Pyrodictium grow in flocs. Cells are disc-shaped and are connected by a network of very thin hollow fibres. Pyrodictium occultum and Pyrodictium brockii are able to grow autotrophically, gaining energy by reduction of $S^{0}$ by $\mathrm{H}_{2}$. Alternatively, these species are able to grow mixotrophically on $\mathrm{H}_{2}$ and thiosulfate in the presence of cell extracts (Table 4). In contrast, Pyrodictium abyssum is an obligate heterotroph, gaining its energy from an up to now unknown type of fermentation. Elemental sulfur stimulates growth, but is not essential (Table 4). A group of coccoid hyperthermophilic sulfate-reducing archaebacteria is represented by Archaeglobus fulgidus $[33,36]$. It is a facultative autotroph. During autotrophic growth, Archaeoglobus fulgidus gains its energy by reduction of thiosulfate by $\mathrm{H}_{2}$ (Table 4). Only very little growth is obtained when thiosulfate is replaced by sulfate under autotrophic conditions. During heterotrophic growth, 
Table 4

Metabolism of hyperthermophiles

\begin{tabular}{|c|c|c|c|c|}
\hline Species & $\begin{array}{l}\text { Autotrophic } \\
\text { growth }\end{array}$ & Substrates & Electron acceptors & End products \\
\hline Sulfolobus acidocaldarius & f & $\mathrm{S}^{0} ; \mathrm{H}_{2} \mathrm{~S} ;$ cell extracts; sugars & $\mathrm{O}_{2}$ & $\mathrm{H}_{2} \mathrm{SO}_{4} ; ?$ \\
\hline Metallosphaera sedula & $\mathbf{f}$ & $\mathrm{S}^{0} ;$ sulfidic ores; cell extracts & $\mathrm{O}_{2}$ & $\mathrm{H}_{2} \mathrm{SO}_{4} ; ?$ \\
\hline Acidianus infernus & o & $\mathrm{S}^{0} ;$ sulfidic ores; $\mathrm{H}_{2}$ & $\mathrm{O}_{2} ; \mathrm{S}^{0}$ & $\mathrm{H}_{2} \mathrm{SO}_{4} ; \mathrm{H}_{2} \mathrm{~S}$ \\
\hline Thermoplasma volcanium & - & Yeast extract; cell extracts & $\mathrm{O}_{2} ; \mathrm{S}^{0}$ & $\begin{array}{l}\text { Acetate, } \mathrm{CO}_{2} \\
\qquad \mathrm{H}_{2} \mathrm{~S} ; ?\end{array}$ \\
\hline Thermoproteus tenax & f & $\mathrm{H}_{2}$; yeast extract; cell extracts & $\mathrm{S}^{0} ; \mathrm{S}_{2} \mathrm{O}_{3}^{2-} ; \mathrm{SO}_{3}^{2-}$ & $\mathrm{H}_{2} \mathrm{~S} ;$ ? \\
\hline Pyrobaculum islandicum & f & $\mathrm{H}_{2}$; yeast extract; cell extracts & $\mathrm{S}^{0} ; \mathrm{S}_{2} \mathrm{O}_{3}^{2-} ; \mathrm{SO}_{3}^{2-} ;$ cystine & $\mathrm{H}_{2} \mathrm{~S} ;$ ? \\
\hline Pyrobaculum organotrophum & - & Yeast extract; cell extracts & $\mathrm{S}^{0} ; \mathrm{S}_{2} \mathrm{O}_{3}^{2-} ; \mathrm{SO}_{3}^{2-} ;$ cystine & $\mathrm{H}_{2} \mathrm{~S} ; ?$ \\
\hline Thermofilum pendens & - & $\begin{array}{l}\text { Yeast extract; tryptone; + lipid } \\
\text { fraction }\end{array}$ & $\mathbf{S}^{0}$ & $\mathrm{H}_{2} \mathrm{~S} ;$ ? \\
\hline Desulfurococcus mobilis & - & Yeast extract; tryptone; casein & $\mathbf{S}^{0}$ & $\mathrm{H}_{2} \mathrm{~S} ;$ ? \\
\hline Staphylothermus marinus & - & $\begin{array}{l}\text { Yeast extract; peptone; meat } \\
\text { extract }\end{array}$ & $\mathbf{S}^{0}$ & $\begin{array}{l}\mathrm{H}_{2} \mathrm{~S} ; \text { acetate; } \\
\quad \text { isovalerate }\end{array}$ \\
\hline Pyrodictium occultum & $f^{b}$ & $\mathrm{H}_{2}\left(\mathrm{H}_{2}+\right.$ cell extract $)$ & $\mathrm{S}^{0} ;\left(\mathrm{S}_{2} \mathrm{O}_{3}^{2-}\right)$ & $\mathrm{H}_{2} \mathrm{~S}$ \\
\hline Pyrodictium abyssum & - & $\begin{array}{l}\text { Yeast extract; gelatine; starch; } \\
\text { formate }\end{array}$ & Fermentative? $\left(\mathbf{S}^{0}\right)$ & $?$ \\
\hline Thermodiscus maritimus & - & Yeast extract; (cell extracts $+\mathrm{H}_{2}$ ) & $\mathrm{S}^{0} ;$ unknown respiration? & $\mathrm{H}_{2} \mathrm{~S} ; ?$ \\
\hline Thermococcus celer & - & Tryptone; yeast extract; casein & $\mathrm{S}^{0} ;$ fermentation? & $\mathrm{H}_{2} \mathrm{~S} ;$ ? \\
\hline Pyrococcus furiosus & - & $\begin{array}{l}\text { Yeast extract; casein; starch; } \\
\text { maltose }\end{array}$ & $\mathrm{S}^{0} ;$ fermentation? & $\mathrm{H}_{2} \mathrm{~S} ; \mathrm{H}_{2} ; \mathrm{CO}_{2} ; ?$ \\
\hline Archaeoglobus fulgidus & $f^{c}$ & $\begin{array}{l}\mathrm{H}_{2} ; \text { formate; lactate; sugars; } \\
\text { proteins }\end{array}$ & $\mathrm{SO}_{4}^{2-} ; \mathrm{S}_{2} \mathrm{O}_{3}^{2-} ; \mathrm{SO}_{3}^{2-}$ & $\begin{array}{l}\mathrm{H}_{2} \mathrm{~S} ; \text { traces } \\
\text { of } \mathrm{CH}_{4}\end{array}$ \\
\hline Methanothermus sociabilis & o & $\mathrm{H}_{2}$ & $\mathrm{CO}_{2}$ & $\mathrm{CH}_{4}$ \\
\hline Methanococcus jannaschii & 0 & $\mathrm{H}_{2}$ & $\mathrm{CO}_{2}$ & $\mathrm{CH}_{4}$ \\
\hline Thermotoga maritima & - & $\begin{array}{l}\text { Yeast extract; sugars; starch; } \\
\text { cellulose }\end{array}$ & Fermentative & $\begin{array}{l}\text { L-Lactate; ace- } \\
\text { tate; } \mathrm{H}_{2} ; \mathrm{CO}_{2}\end{array}$ \\
\hline Thermotoga thermarum & - & $\begin{array}{l}\text { Yeast extract; (yeast extract }+ \\
\text { carbohydrates) }\end{array}$ & Fermentative & n.d. \\
\hline
\end{tabular}

$o=$ obligately autotrophic; $f=$ facultatively autotrophic; - = heterotrophic.

b Autotrophic growth only with $\mathbf{S}^{\mathbf{0}}$ as electron acceptor.

c Autotrophic growth only with $\mathrm{S}_{2} \mathrm{O}_{3}^{2-}$ as electron acceptor.

n.d. $=$ not determined.

various substrates like lactate, formate, glucose, starch and proteins can be used. As electron acceptors, sulfate, thiosulfate, and sulfite can be used heterotrophically. $S^{0}$ is inhibitory during autotrophic and heterotrophic growth. In addition, traces of methane (up to $0.1 \mu \mathrm{mol} / \mathrm{ml}$ ) are formed via an unknown pathway [36]. Similar to the methanogens, cells of Archaeoglobus show a bluegreen fluorescence at $420 \mathrm{~nm}$ due to the posses- sion of factor 420 [36]. Due to its unique type of RNA polymerase and its 16S rRNA sequence, Archaeoglobus forms a separate phylogenetic branch situated between the thermophilic sulfur metabolizers and the methanogens [33,36,37]. A further autotrophic marine hyperthermophile is represented by Methanococcus jannaschii, which had been isolated up to now only from submarine deep sea vents (34). Methanococcus jannaschii is a 
strictly autotrophic methanogen growing at temperatures up to $86^{\circ} \mathrm{C}$ (Table 3,4).

The marine thermal environment contains also a variety of strictly heterotrophic hyperthermophiles. Members of the genus Staphylothermus are obligate sulfur respirers. Cells of Staphylothermus marinus are coccoid and grow in grape-like aggregates and form giant cells under special nutritional conditions [30]. Cells of isolates of the genus Thermodiscus are disc-shaped. In contrast to Pyrodictium, they do not form fibres, grow only up to $98^{\circ} \mathrm{C}$ and show a much lower GC-content of their DNA (Table 3, 4). Growth occurs by sulfur respiration on yeast- and cell extracts and is stimulated by $\mathrm{H}_{2}$. Good growth is also obtained without sulfur possibly due to an unknown respiration of fermentation. The genera Thermococcus and Pyrococcus are belonging to the Thermococcales, which represent up to now the deepest branch-off within the phylogenetic archaebacterial tree $[7,31,32,38]$. The cells are coccoid shaped (Table 3). Thermococcus celer utilizes tryptone, yeast extract and protein as carbon sources. Growth is stimulated by sucrose. In closed culture vessels, Thermococcus celer grows optimally in the presence of sulfur and about $1.5 \mathrm{~mol}$ of $\mathrm{H}_{2} \mathrm{~S}$ are formed per mole of $\mathrm{CO}_{2}$ [31]. Thermococcus can also grow without sulfur. Under optimal conditions, the generation time of Thermococcus celer is close to $50 \mathrm{~min}$. Pyrococcus furiosus grows at temperatures up to $103^{\circ} \mathrm{C}$ and shows a much lower GC content than Thermococcus celer (Table 3). At $100^{\circ} \mathrm{C}$, the doubling time is only $37 \mathrm{~min}$ [32]. Cells of Pyrococcus furiosus are highly motile due to monopolar polytrichous flagellation, They grow on yeast extract, peptone, casein, starch and maltose and possess a powerful protease and amylase. As metabolic products in the absence of sulfur $\mathrm{CO}_{2}$ and $\mathrm{H}_{2}$ were found, the latter being inhibitory to growth. Hydrogen inhibition can be prevented by the addition of $S^{0}$, whereupon $\mathrm{H}_{2} \mathrm{~S}$ is formed in addition. The mode of fermentation of Pyrococcus and Thermococcus is still unclear. Many submarine hydrothermal fields contain also members of the eubacterial genus Thermotoga which are thriving together with hyperthermophilic archaebacteria in the same environment. Thermotoga maritima and Thermotoga neapolitana are fermentative hyperthermophiles growing at temperatures up to $90^{\circ} \mathrm{C}$ (Table 3; $[6,39])$. They are using various carbohydrates as energy source. As end products, L-lactate, acetate, $\mathrm{H}_{2}$ and $\mathrm{CO}_{2}$ are formed (Table 4). Hydrogen is inhibitory to growth and has to be removed during cultivation. In the presence of $\mathrm{S}^{0}, \mathrm{H}_{2} \mathrm{~S}$ is formed and $\mathrm{H}_{2}$ inhibition is overcome [6].

\section{CONCLUSIONS}

The isolation of various groups of hyperthermophilic bacteria from geothermally and hydrothermally heated environments demonstrates an unexpected complexity of these up to now almost unexplored ecosystems. Within these, primary production and consumption of organic matter is going on at temperatures around $100^{\circ} \mathrm{C}$. The energy-yielding reactions of primary production is based on reduction or oxidation of inorganic sulfur compounds by $\mathrm{H}_{2}$ or $\mathrm{O}_{2}$, or in the case of methanogens on reduction of $\mathrm{CO}_{2}$ by $\mathrm{H}_{2}$. Since $\mathrm{H}_{2}$, $\mathrm{CO}_{2}$ and $\mathrm{S}^{0}$ are formed within the environment, anaerobic autotrophs using these compounds are completely independent of sunlight. The consumers of organic matter are most likely using cell components of the decaying primary producers. Most of them are growing by sulfur respiration or by unknown types of respiration and fermentation. A great deal of the autotrophs are 'opportunistic' heterotrophs, too. This property may be important for effective competition within the extreme environment.

The upper temperature border of life is still unknown. The existence of Pyrodictium and other hyperthermophiles demonstrates that still unrecognized thermostabilizing principles must exist. Since stability of biomolecules at temperatures above $100^{\circ} \mathrm{C}$ decreases rapidly [40-42], the maximal growth temperature at which microbial life can exist may be possibly found between 110 and $150^{\circ} \mathrm{C}$. Within this temperature range, heat-sensitive biomolecules could possibly still be resynthesized at biologically feasible rates. Beyond the interesting questions in basic research, hyperthermophiles may be well suited for the development of novel biotechnological processes due to their 
novel metabolic properties and the outstanding heat resistance of their cell components.

\section{ACKNOWLEDGEMENTS}

We would like to thank Ch. Stadler for typing the manuscript.

\section{REFERENCES}

[1] Brock, T.D. (1978) Thermophilic Microorganisms and Life at High Temperatures. Springer-Verlag, Berlin, Heidelberg. New York.

[2] Stetter, K.O. and Zillig, W. (1985) Thermoplasma and the thermophilic sulfur-dependent archaebacteria. In The Bacteria, Vol. VIII. (Wolfe, R.S. and Woese, C.R. Eds.), pp. 85-170 Academic Press, New York.

[3] Stetter, K.O. (1986) Diversity of extremely thermophilic archaebacteria In Thermophiles, General, Molecular and Applied Microbiology (Brock, T.D. ed.), pp. 39-74. Wiley and Sons, New York, London, Sydney, Toronto.

[4] Stetter, K.O., König, H. and Stackebrandt, E. (1983) Pyrodictium gen. nov., a new genus of submarine discshaped sulphur reducing archaebacteria growing optimally at $105^{\circ} \mathrm{C}$. Syst. Appl. Microbiol. 4, 535-551.

[5] Woese, C.R., Magrum, L.J. and Fox, G.E. (1978) Archaebacteria. J. Mol. Evol. 11, 245-252.

[6] Huber, R., Langworthy, T.A., König, H., Thomm, M., Woese, C.R., Sleytr, U.B. and Stetter, K.O. (1986) Thermotoga maritima sp. nov. represents a new genus of unique extremely thermophilic eubacteria growing up to $90^{\circ} \mathrm{C}$. Arch. Microbiol. 144, 324-333.

[7] Woese, C.R. (1987) Bacterial evolution. Microbiol. Rev. 51, 221-227.

[8] Stetter, K.O., Segerer, A., Zillig, W., Huber, G., Fiala, G., Huber, R. and König, H. (1986) Extremely thermophilic sulfur-mobilizing archaebacteria. Syst. Appl. Microbiol. 7, 393-397.

[9] Huber, R., Kristjansson, J.K. and Stetter, K.O. (1987) Pyrobaculum gen. nov., a new genus of neutrophilic, rodshaped archaebacteria from continental solfataras growing optimally at $100^{\circ} \mathrm{C}$. Arch. Microbiol. 149, 95-101.

[10] Segerer, A., Langworthy, T.A. and Stetter, K.O. (1988) Thermoplasma acidophilum and Thermoplasma volcanium sp. nov. from solfatara fields. Syst. Appl. Microbiol. 10, 161-171.

[11] Brock, T.D., Brock, K.M., Belly, R.T. and Weiss, R.L. (1972) Sulfolobus: a new genus of sulfur-oxidizing bacteria living at low $\mathrm{pH}$ and high temperature. Arch. Mikrobiol. 84, 54-68.

[12] Marsh, R.M., Norris, P.R. and Le Roux, N.W. (1983) Growth and mineral oxidation studies with Sulfolobus In Recent Progress in Biohydrometallurgy (Rossi G., and
Torma, A., Eds.). pp. 71-81. Associazione Mineraria Sarda, Iglesias.

[13] Huber, G., Huber, H. and Stetter, K.O. (1986) Isolation and characterization of new metal-mobilizing bacteria. Biotechn. Bioeng. Symp. 16, 239-251.

[14] Huber, G. (1988) Isolierung, Charakterisierung und taxonomische Einordnung neuer thermophiler, metalImobilisierender Archaebakterien. Thesis, University of Regensburg, Regensburg.

[15] Huber, G., Spinnler, C., Gambacorta, A. and Stetter, K.O. (1989) Metallosphaera sedula gen. nov. and sp. nov. represents a new genus of aerobic, metal-mobilzing. thermoacidophilic archacbacteria. Syst. Appl. Microbiol. 12, 3847.

[16] Brock, T.D. and Gustafson, J. (1976) Ferric iron reduction by sulfur- and iron-oxidizing bacteria. Appl. Environm. Microbiol. 32, 567-571.

[17] Brierley, C.L. and Brierly, J.A. (1982) Anaerobic reduction of molybdenum by Sulfolobus species. Zbl. Bakteriol. Hyg., I. Abt. Orig. C 3, 289-294.

[18] Segerer, A., Stetter, K.O. and Klink, F. (1985) Two contrary modes of chemolithotrophy in the same archaebacterium. Nature 313, 787-789.

[19] Segerer, A., Neuner, A., Kristjansson, J.K. and Stetter, K.O. (1986) Acidianus infernus gen. nov., sp. nov., and Acidianus brierleyi comb. nov.: facultatively aerobic, extremely acidophilic thermophilic sulfur-metabolizing archaebacteria. Int. J. Syst. Bact. 36. 559-564.

[20] Zillig, W., Yeast, S., Holz, I., Böck, A., Gropp, F., Rettenberger, M. and Lutz, S. (1985) Plasmid-related anaerobic autotrophy of the novel archaebacterium Sulfolobus ambivalens. Nature 313, 789-791.

[21] Zillig. W., Yeast, S., Holz, I., Böck, A., Gropp, F. and Simon, G. (1987) Desulfurolobus ambivalens, gen. nov., sp. nov., an autotrophic archaebacterium facultatively oxidizing or reducing sulfur. Syst. Appl. Microbiol. 8, 197-203.

[22] Huber, R., Huber, G., Segerer, A., Seger, J. and Stetter, K.O. (1987) Aerobic and anaerobic extremely thermophilic autotrophs In Microbial growth on $C_{1}$ compounds (Van Verseveld, H.W. and Duine, J.A., Eds.), pp. 44-51. Proc. Sth Int. Symp., Martinus Nijhoff, Dordrecht.

[23] Zillig, W., Stetter, K.O., Schäfer, W., Janekovic, D., Wunderl, S., Holz, I. and Palm, P. (1981) Thermoproteales: a novel type of extremely thermoacidophilic anaerobic archaebacteria isolated from Icelandic solfataras. Zbl. Bakt. Hyg., I. Abt. Orig. C 2, 205-227.

[24] Zillig, W., Gierl, A., Schreiber, G., Wunderl, S., Janekovic, D., Stetter, K.O. and Klenk, H.P. (1983) The archaebacterium Thermofilum pendens represents a novel genus of the thermophilic, anaerobic, sulfur respiring Thermoproteales. Syst. Appl. Microbiol. 4, 79-87.

[25] Zillig, W., Stetter, K.O., Prangishvilli, D., Schäfer, H., Wunderl, S., Janekovich, D., Holz, I. and Palm, P. (1982) Desulfurococcaceae, the second family of the extremely thermophilic anaerobic sulfur respiring Thermoproteales. Zb. Bakt. Hyg., I. Abt. Orig. C 3, 304-317.

[26] Stetter, K.O., Thomm, M., Winter, J., Wildgruber, G., Huber, H.; Zillig, W., Janecovic, D., König, H., Palm, P. 
and Wunderl, S. (1981) Methanothermus fervidus, sp. nov., a novel extremely thermophilic methanogen from an Icelandic hot spring. Zbl. Bakt. Hyg., I. Abt. Orig. C 2 , 166-178.

[27] Fischer, F., Zillig, W., Stetter, K.O. and Schreiber, G. (1983) Chemolithoautotrophic metabolism of anaerobic extremely thermophilic archaebacteria. Nature 301, 511513.

[28] Lauerer, G., Kristjansson, J.K., Langworthy, T.A., König, H. and Stetter, K.O. (1986) Methanothermus sociabilis sp. nov., a second species within the Methanothermaceae growing at $97^{\circ} \mathrm{C}$. Syst. Appl. Microbiol. 8, 100-105.

[29] Windberger, E., Huber, R., Trincone, A., Fricke, H. and Stetter, K.O. (1989) Thermotoga thermarum sp. nov. and Thermotoga neapolitana occurring in African continental solfataric springs. Arch. Microbiol. 151, 506-512.

[30] Fiala, G., Stetter, K.O., Jannasch, H.W., Langworthy, T.A. and Madon, J. (1986) Staphylothermus marinus sp. nov. represents a novel genus of extremely thermophilic submarine heterotrophic archaebacteria growing up to $98^{\circ} \mathrm{C}$. Syst. Appl. Microbiol. 8, 106-113.

[31] Zillig, W., Holz, I., Janekovic, D., Schäfer, W. and Reiter, W.D. (1983) The archaebacterium Thermococcus celer represents a novel genus within the thermophilic branch of the archaebacteria. Syst. Appl. Microbiol. 4, 88-94.

[32] Fiala, G. and Stetter, K.O. (1986) Pyrococcus furiosus sp. nov. represents a novel genus of marine heterotrophic archaebacteria growing optimally at $100^{\circ} \mathrm{C}$. Arch. Microbiol. 145, 56-61.

[33] Stetter, K.O. (1988) Archaeoglobus fulgidus gen. nov., sp. nov.: a new taxon of extremely thermophilic archaebacteria. Syst. Appl. Microbiol. 10, 172-173.
[34] Jones, W.J., Leigh, J.A., Mayer, P., Woese. C.R. and Wolfe, R.S. (1983) Methanococcus jannaschii sp. nov., an extremely thermophilic methanogen from a submarine hydrothermal vent. Arch. Microbiol. 136, 254-261.

[35] Stetter, K.O. (1982) Ultrathin mycelia-forming organisms from submarine volcanic areas having an optimum growth temperature of $105^{\circ} \mathrm{C}$. Nature $300,258-260$.

[36] Stetter, K.O., Lauerer, G., Thomm, M. and Neuner, A. (1987) Isolation of extremely thermophilic sulfate reducers: evidence for a novel branch of archaebacteria. Science 236, 822-824.

[37] Achenbach-Richter, L., Stetter, K.O. and Woese, C.R. (1987) A possible biochemical missing link among archaebacteria. Nature 327, 348-349.

[38] Zillig, W., Holz, I., Klenk, H.P., Trent, J., Wunderl, S., Janecovic, D., Imsel, E. and Haas, B. (1987) Pyrococcus woesei, sp. nov., an ultra-thermophilic marine archaebacterium representing a novel order, Thermococcales. Syst. Appl. Microbiol. 9, 62-70.

[39] Jannasch, H.W., Huber, R., Belkin, S. and Stetter, K.O. (1988) Thermotoga neapolitana sp. nov. of the extremely thermophilic, eubacterial genus Thermologa. Arch. Microbiol. 150, 103-104.

[40] White, R.H. (1984) Hydrolytic stability of biomolecules at high temperatures and its implication for life at $250^{\circ} \mathrm{C}$. Nature 310, 430-431.

[41] Bernhardt, G., Lüdemann, H.D., Jaenicke, R., König. H. and Stetter, K.O. (1984) Biomolecules are unstable under 'black smoker' conditions. Naturwissenschaft 71, 583-585.

[42] Trent, J.D., Chastain, R.A. and Yayanos, A.A. (1984) Possible artefactual basis for apparent bacterial growth at $250^{\circ} \mathrm{C}$. Nature 207, 737-740. 